\title{
Developmental increases in plasma leptin binding activity and tissue Ob-Re mRNA expression in the rat
}

\author{
Jeremy T Smith, Peter J Mark and Brendan J Waddell \\ School of Anatomy and Human Biology, The University of Western Australia, 35 Stirling Hwy Crawley, Perth, Western Australia 6009, Australia \\ (Requests for offprints should be addressed to B Waddell; Email: bwaddell@anhb.uwa.edu.au)
}

\begin{abstract}
Leptin's actions are mediated via the long form of its receptor, $\mathrm{Ob}-\mathrm{Rb}$, but access to this receptor on target cells is also influenced by truncated leptin receptor isoforms $\mathrm{Ob}-\mathrm{Ra}$ and $\mathrm{Ob}-\mathrm{Re}$. Plasma leptin binding activity is primarily attributed to $\mathrm{Ob}-\mathrm{Re}$, which can restrict leptin passage to extravascular tissue. In this study we investigated whether plasma leptin binding activity changes from fetal to adult life in male and female rats, and whether tissue expression of $\mathrm{Ob}-\mathrm{Re}$ mRNA changes during development. Plasma leptin binding activity was low in the fetus and prepubertal rats but then increased in male rats by more than three-fold from pre- to post-puberty and by a further two-fold by 7 months of age. A more modest increase in plasma leptin binding activity was observed in females such that a clear sex difference became evident after puberty. There was also a reduction in hypothalamic $\mathrm{Ob}-\mathrm{Rb}$ protein content between puberty and adult life in female rats. Combined with the higher levels of plasma leptin binding activity, this change in hypothalamic
\end{abstract}

$\mathrm{Ob}-\mathrm{Rb}$ expression is likely to lead to a more leptinresistant state in aging females. To assess possible sources of circulating leptin binding activity, Ob-Re mRNA expression was measured by quantitative RT-PCR in several tissues from male rats soon after puberty and at 7 months of age. All tissues examined (testis, epididymis, adrenal, liver, adipose and spleen) expressed Ob-Re mRNA, and there was a dramatic, age-related increase in expression (>300-fold) in the spleen. These data show that, in addition to the developmental increase in hypothalamic $\mathrm{Ob}-\mathrm{Rb}$ expression previously reported, plasma leptin binding activity increases several fold from fetal to adult life in the rat. This suggests that the actions of leptin depend not only on its synthesis in adipose tissue and $\mathrm{Ob}-\mathrm{Rb}$ expression in target cells, but also on factors that regulate tissue expression of $\mathrm{Ob}-\mathrm{Re}$ and thus leptin transport within plasma.

Journal of Endocrinology (2005) 184, 535-541

\section{Introduction}

Leptin, the $16 \mathrm{kDa}$ peptide product of the $o b$ gene, is synthesized primarily by adipocytes and acts via the hypothalamus to decrease food intake and increase metabolic rate (Campfield et al. 1995, Pelleymounter et al. 1995). Leptin also impacts on a range of other physiological processes including immune (Clarke \& Henry 1999, Henson \& Castracane 2000) and reproductive function (Loffreda et al. 1998, Fantuzzi \& Faggioni 2000), most notably by providing a key signal for the timing of puberty (Cheung et al. 1997, Nagatani et al. 1998). Accordingly, puberty onset in $o b / o b$ mice occurs only after administration of exogenous leptin (Zhang et al. 1994). The leptin receptor is a member of the class I cytokine receptor family and six multiple splice variants have been identified in rodents (Tartaglia 1997). These splice variants fall into three categories: a long form (Ob-Rb), located primarily within the hypothalamus, capable of full signal transduction; a number of C-terminally truncated forms including $\mathrm{Ob}-\mathrm{Ra}$ which is thought to act as a transporter of leptin; and a soluble receptor (Ob-Re) that lacks both the intracellular and transmembranous domains and acts as a circulating leptin binding protein. In rodents, the $\mathrm{Ob}-\mathrm{Re}$ isoform is encoded by a specific mRNA and is secreted (Gavrilova et al. 1997, Tartaglia 1997, Huang et al. 2001), whereas in the human it is derived from shedding of the extracellular portion of membrane-bound leptin receptors (Ge et al. 2002). Regardless of its origin, leptin binding to soluble leptin receptors is now recognised as an important regulator of leptin access to target and metabolic tissues (Huang et al. 2001, Elefteriou et al. 2004). Indeed, a dramatic increase in plasma leptin binding activity in rodent pregnancy (Gavrilova et al. 1997, Seeber et al. 2002) reduces the metabolic clearance rate (MCR) of maternal leptin (Smith \& Waddell 2003b) and thus contributes to the marked rise in maternal plasma leptin levels (Gavrilova et al. 1997, Seeber et al. 2002). While the placenta is the major source of this binding activity in pregnancy (Gavrilova et al. 1997, 
Smith \& Waddell 2002), its source and variability in non-pregnant animals is unknown. Recently, we demonstrated that hypothalamic $\mathrm{Ob}-\mathrm{Rb}$ expression increases progressively from the late fetal to the peripubertal period in both sexes (Smith \& Waddell 2003a). These data suggest that enhanced responsiveness of the hypothalamus to leptin may contribute to puberty onset, but whether plasma leptin binding activity also changes during development, particularly in the peripubertal period, is unknown. Studies across human development show that circulating leptin binding activity falls from pre- to postpuberty (Quinton et al. 1999, Kratzsch et al. 2002, Mann et al. 2003), suggesting that access of plasma leptin to its hypothalamic targets may be enhanced over this period. In the present study, therefore, we measured plasma leptin binding activity in fetal, prepubertal, postpubertal and adult male and female rats. This analysis showed a clear increase in plasma leptin binding activity over development, particularly in males, and so to assess possible sources of this binding activity Ob-Re mRNA expression was determined in a range of tissues from young and adult rats.

\section{Materials and Methods}

\section{Animals}

Albino Wistar rats aged between 9 and 12 weeks were obtained from the Animals Resources Centre (Murdoch, Australia) and maintained under controlled conditions as previously described (Burton \& Waddell 1994). Rats were mated overnight and the day on which spermatozoa were present in vaginal smear was designated gestational day 1 (g1). The day of birth, usually g23 in this colony of rats, was designated postnatal day 0 (p0). Pup sex was determined by examination of external genital morphology and litters were standardised to 10 pups before the third day postpartum and, where applicable, were weaned on p30. The onset of puberty was deemed to occur at the time of vaginal opening in females and preputial separation in males (Smith \& Waddell 2000). All procedures involving animals were conducted only after approval by the Animal Ethics Committee of The University of Western Australia.

\section{Blood sampling and tissue collection}

At g22 pregnant rats were anesthetized with halothane/ nitrous oxide and fetuses removed. Blood samples were obtained by decapitation from 4 female and 4 male g22 fetuses (from a single litter) and pooled to provide sufficient volume. Blood samples were collected from anesthetised rats at $\mathrm{p} 12$ by decapitation, and at $\mathrm{p} 30$ and $\mathrm{p} 51$ via the exposed dorsal aorta. Brains were removed from rats at p51 and 7 months of age and the hypothalamus dissected (Zakrzewska et al. 1999) and immediately frozen in liquid nitrogen. Tissue samples for $\mathrm{Ob}-\mathrm{Re}$ mRNA analysis (spleen, liver, adipose, adrenal, testis and epididymis) were obtained from separate groups of anaesthetised male rats at p51 and 7 months and immediately frozen in liquid nitrogen for subsequent real-time quantitative RT-PCR.

\section{Plasma leptin binding activity}

Plasma leptin binding activity was assayed as described previously (Gavrilova et al. 1997, Seeber et al. 2002). Briefly, plasma samples $(5 \mu \mathrm{l})$ were incubated with $5 \mu \mathrm{l}$ of ${ }^{125}$ I-leptin (approximately $5 \mathrm{ng} / \mathrm{ml}$ and 20000 c.p.m.) overnight at $4{ }^{\circ} \mathrm{C}$. Sample buffer $(20 \mu \mathrm{l})$ containing bromophenol blue was added, samples were vortexed and electrophoresed in $12 \%$ Tris/glycine gels at $160 \mathrm{~V}$. The gel was dried and placed against film for $48 \mathrm{~h}$ at $-80^{\circ} \mathrm{C}$. The band corresponding to specifically bound ${ }^{125}$ I-leptin was scanned and leptin binding activity quantified by analysis of pixel intensity using Scion Image analysis software (Release beta 3b; Scion Corporation, Frederick, MD, USA) as previously described (Burton et al. 1998).

\section{Radioimmunoassays}

Blood samples collected as described above were centrifuged at $13000 \mathrm{~g}$ for $5 \mathrm{~min}$ and plasma stored at $-20{ }^{\circ} \mathrm{C}$ until assayed. Plasma leptin concentrations were measured using a radioimmunoassay kit supplied by Linco Research (St Charles, MO, USA). The intra- and inter-assay coefficients of variation were $4 \%$ and $8 \%$ respectively.

\section{Western blot analysis of hypothalamic $\mathrm{O} b-\mathrm{R} b$}

Hypothalamic $\mathrm{Ob}-\mathrm{Rb}$ protein expression was measured in postpubertal (p51) and adult rats (7 months of age) as previously described (Seeber et al. 2002). Briefly, hypothalami were homogenized $(10 \mathrm{mM}$ Tris buffer containing $1.5 \mathrm{mM}$ EDTA, $1 \mathrm{mM}$ DTT, $1 \mathrm{mM}$ PMSF and $100 \mu \mathrm{g} / \mathrm{ml}$ trypsin inhibitor) then centrifuged at $105000 \boldsymbol{g}$ for $30 \mathrm{~min}$. Supernatant protein $(30 \mu \mathrm{g})$ was resolved by $7 \%$ SDS-PAGE electrophoresis and transferred to nitrocellulose membrane (Hybond C Super, Amersham Biosciences, Australia). Membranes were blocked in Trisbuffered saline (TBS)-Tween (0.1 M Tris, $0.15 \mathrm{M} \mathrm{NaCl}$, $0 \cdot 1 \%$ Tween-20; $\mathrm{pH} 7 \cdot 5)$ containing $5 \%$ non-fat milk powder for $1 \mathrm{~h}$ then exposed for $2 \mathrm{~h}$ to leptin receptor antibody (K-20, Santa Cruz Biotechnology; 1:400 dilution in TBS-Tween buffer, containing $1 \%$ non-fat milk powder). Membranes were washed then incubated with a horseradish peroxidase-conjugated donkey anti-goat secondary antibody (1:5000; Santa Cruz Biotechnology) for $1 \mathrm{~h}$. Immunoreactive bands were visualised using a chemiluminescence detection kit (SuperSignal Substrate, Pierce Chemical, Rockford, IL, USA), with membranes placed against film for $1 \mathrm{~min}$, and resultant images quantified by 
densitometry using Scion Image analysis software (Release beta 3b) as previously described (Burton et al. 1998).

\section{Real-time quantitative RT-PCR}

Total RNA was isolated from various tissues (adipose, liver, spleen, adrenal, testis and epididymis) obtained from postpubertal (p51) and adult (7 months of age) rats using RNAzol (Iso-Tex Diagnostics, Friendswood, TX, USA), except for adipose tissue which used RNeasy Lipid Tissue Mini Kit (Qiagen, Clifton Hill, Australia). The purified RNA $(5 \mu \mathrm{g})$ was reverse transcribed and the resultant cDNA purified and quantified as previously described (Seeber et al. 2002). Primers specific to rat Ob-Re (Takaya et al. 1996) and L19 as a housekeeping internal control (Orly et al. 1994) were used for amplification and spanned introns to distinguish cDNA from genomic DNA, and external standards were generated from regular PCR products. Quantitative PCR and melting curve analyses were performed in $10 \mu \mathrm{l}$ reaction volumes in capillary tubes using the LightCycler system (Roche Diagnostics, Indianapolis, IN, USA) as previously described (Smith \& Waddell 2002). Fluorescence values were analysed and a standard curve constructed using the LightCycler software, and sample values were expressed relative to L19 expression.

\section{Statistical analysis}

All data are expressed as the mean \pm S.E.M. where a minimum of three animals were used for each experimental variable and each litter represented an ' $n$ ' of one. Variation in plasma leptin binding activity related to age and sex was assessed by one- or two-way ANOVA, and differences among specific means were determined by LSD test (Snedecor \& Cochran 1989). Unpaired $t$-tests were used to compare plasma leptin, leptin binding activity and hypothalamic $\mathrm{Ob}-\mathrm{Rb}$ protein expression between male and female rats at any given age. For tissue expression of Ob-Re mRNA, the data were first log transformed to adjust for unequal variance, then analysed by two-way ANOVA.

\section{Results}

\section{Plasma leptin binding activity}

Plasma leptin binding activity varied significantly with both age $(P<0 \cdot 001)$ and sex $(P<0 \cdot 05)$ and there was significant interaction between these sources of variation $(P<0 \cdot 05$; Fig. 1). Therefore, age-related changes were assessed separately in males and females by one way ANOVAS. In females, plasma leptin binding activity increased gradually from very low levels at g22 and p12 to a maximum at 7 months $(P<0 \cdot 05)$. A more dramatic increase $(P<0.001)$ was observed in male rats, rising more than three-fold from pre- to post-puberty $(P<0.05)$ and then by a further two-fold from post-puberty to seven months $(P<0 \cdot 05)$. Therefore, while plasma leptin binding activity was similar in male and female rats at prepubertal stages, it was higher $(P<0 \cdot 05)$ in males after puberty ( $\mathrm{p} 51$ and 7 months).

\section{Hypothalamic $\mathrm{Ob}-\mathrm{Rb}$ protein expression}

We previously demonstrated that hypothalamic $\mathrm{Ob}-\mathrm{Rb}$ protein expression was higher in females compared with males in the immediate post-pubertal period (Smith \& Waddell 2003a). A similar difference in Ob-Rb expression was observed at day 51 in the present work (females 21\% greater, $P<0 \cdot 05)$, but by seven months of age this sex difference was no longer apparent (Fig. 2). Plasma leptin concentrations at seven months of age were quite variable and did not differ significantly between males $(9 \cdot 0 \pm 1 \cdot 0 \mathrm{ng} / \mathrm{ml})$ and females $(6 \cdot 1 \pm 1 \cdot 0 \mathrm{ng} / \mathrm{ml} ; P=0 \cdot 10)$, even though males were $37 \%$ heavier than females (males, $533 \pm 5$ g; females, $334 \pm 9$ g; $P<0 \cdot 001)$.

\section{Developmental changes in $\mathrm{Ob}-\mathrm{Re} m \mathrm{RN} A$ expression}

Expression of mRNA encoding the Ob-Re isoform of the leptin receptor was detected in all tissues examined at day 51 and at 7 months (Fig. 3). Expression levels varied with both age $(P<0 \cdot 01)$ and tissue $(P<0 \cdot 01)$ and there was significant interaction between these sources of variation $(P<0 \cdot 01)$. Therefore, specific age comparisons were made by unpaired $t$-tests and these showed age-related increases in Ob-Re mRNA expression in the spleen (300-fold increase, $P<0 \cdot 01)$, testis $(2 \cdot 4$-fold, $P<0 \cdot 05)$ and adipose tissue (2-fold, $P<0 \cdot 05$ ).

\section{Discussion}

In the present study we show that a marked increase in plasma leptin binding activity occurs across development in the rat, and this is associated with upregulation of Ob-Re mRNA expression in a number of tissues, most notably the spleen. Leptin actions are mediated via $\mathrm{Ob}-\mathrm{Rb}$ on target cells but are also influenced by at least two truncated receptor isoforms, Ob-Ra and Ob-Re. Thus, $\mathrm{Ob}-\mathrm{Ra}$ is thought to facilitate leptin transport across anatomical barriers such as the blood-brain barrier (Kastin et al. 1999) and the placenta (Smith \& Waddell 2003b), whereas the soluble form of the leptin receptor, Ob-Re, serves as a plasma binding protein that limits access of leptin to extravascular tissues and thus target cells. Such a role for circulating Ob-Re is supported by reports showing that adenovirus-mediated overexpression of Ob-Re increases plasma leptin binding activity and limits the effect of leptin on target tissues in mice (Huang et al. 2001, 


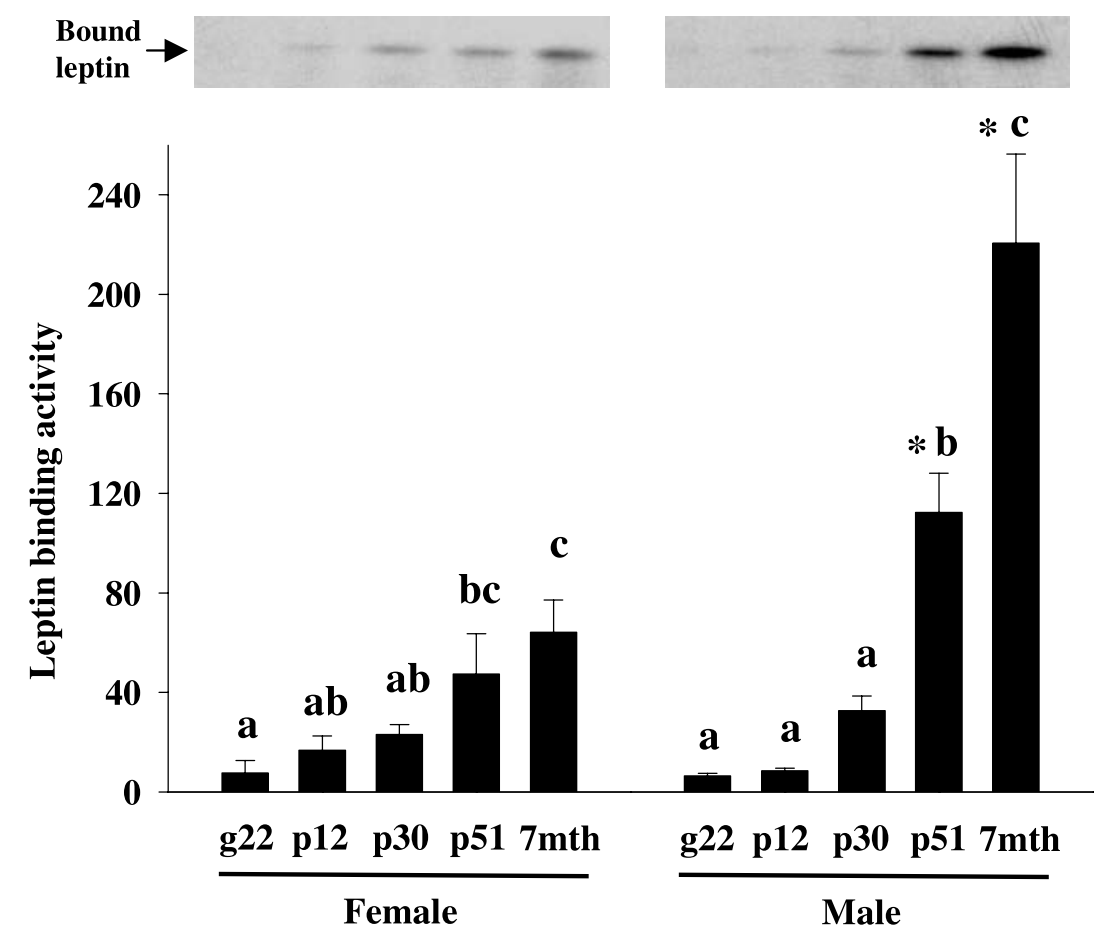

Figure 1 Changes in plasma leptin binding activity at gestational day 22 (g22), postnatal (p) days 12, 30 and 51 and at seven months ( $7 \mathrm{mth}$ ) of age in female and male rats. Values are expressed in arbitrary density units and are the mean \pm S.E.M. of $n=4$ per group. Significant variation occurred with age $(P<0 \cdot 001)$ and sex $(P<0 \cdot 01)$ and there was significant interaction $(P<0 \cdot 01)$ between these sources of variation. Within each group (male or female), values without common notations ( $a, b$ and $c)$ differ significantly $\left(P<0 \cdot 05\right.$; LSD-test). ${ }^{*} P<0.05$ compared with corresponding age in females (unpaired t-test).

Elefteriou et al. 2004). Because the developmental rise in plasma leptin binding occurred on a background of increasing hypothalamic expression of $\mathrm{Ob}-\mathrm{Rb}$ (Smith \& Waddell 2003a), it is apparent that leptin actions are determined by the complex interplay of leptin secretion by adipose tissue, leptin transport within and from the vascular compartment, and target tissue expression of $\mathrm{Ob}-\mathrm{Rb}$.

The developmental increase in plasma leptin binding activity was clearly more pronounced in males than females, rising several-fold between late fetal life and adulthood. Because this sex difference emerged only after puberty it may reflect the action of sex steroids, with testosterone stimulating and/or ovarian steroids inhibiting tissue expression of Ob-Re. Estrogen appears to suppress $\mathrm{Ob}-\mathrm{Rb}$ expression in the rat choroid plexus, hypothalamus (Bennett et al. 1999) and ovary (Duggal et al. 2002), although in the baboon placenta estrogen suppression induced by fetectomy was recently shown to reduce placental expression of the long form of Ob-R (Edwards et al. 2004). Interestingly, a putative estrogen response element has been identified on the Ob-R promoter in the rat (Lindell et al. 2001), but it remains unclear how this might influence tissue expression of the specific Ob-R isoforms, including Ob-Re. In humans, plasma leptin binding activity is also higher in males but, surprisingly, plasma leptin binding activity is associated negatively with plasma testosterone in males and positively with estrogen in females (Mann et al. 2003). Clearly, further studies are required to determine the mechanisms underlying sex differences in plasma leptin binding activity in both rodents and humans.

The increase in plasma leptin binding is likely to reduce the MCR of leptin relative to body weight, an effect recently observed in rat pregnancy (Smith \& Waddell 2003b). This reduction in leptin MCR occurred just prior to term, coincident with maximal levels of leptin binding activity (Smith \& Waddell 2003b) and likely reflects retention of leptin within the vascular compartment. During early postnatal development plasma leptin levels exhibit a dynamic pattern in both males and females, but then after puberty leptin rises more quickly in male rats (Smith \& Waddell 2003a). The present study suggests that this divergence partly reflects the more rapid increase in plasma leptin binding activity and the associated fall in relative MCR of leptin in males. 


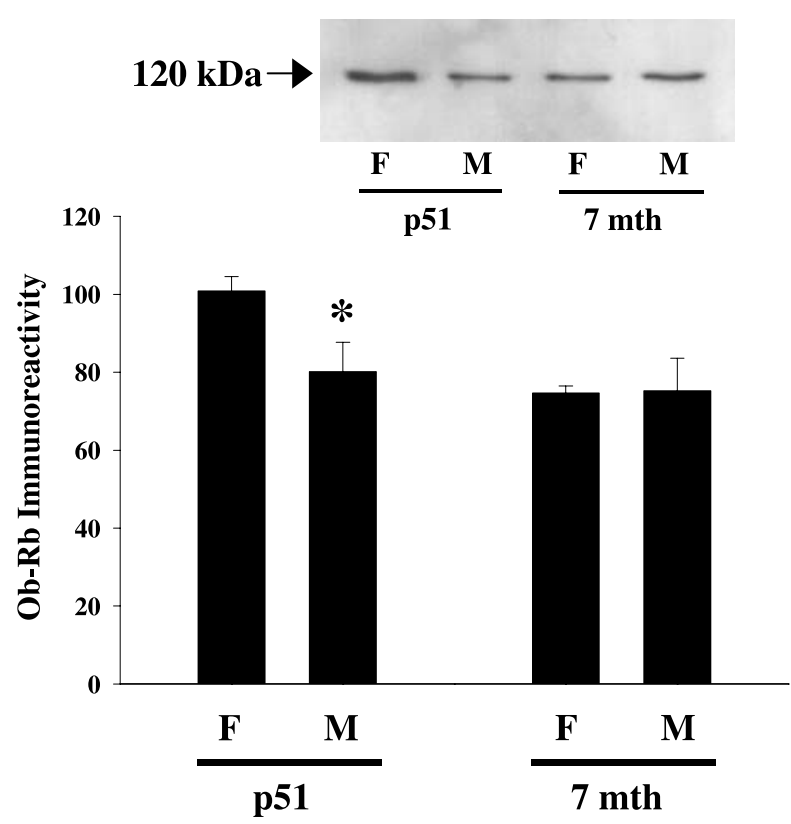

Figure 2 Western blot analysis and quantification of hypothalamic $\mathrm{Ob}-\mathrm{Rb}$ protein in male $(\mathrm{M})$ and female $(\mathrm{F})$ rats at postnatal day 51 (p51) and at 7 months of age (7 mth). Values are expressed in arbitrary density units and are the mean \pm S.E.M of $n=4$ per group. ${ }^{*} P<0 \cdot 05$ compared with female p51 value (unpaired $t$-test).
In addition to limiting leptin metabolism, increased plasma leptin binding activity is likely to restrict leptin access to $\mathrm{Ob}-\mathrm{Rb}$ on target cells and thus result in a state of relative leptin resistance, comparable to that apparent in pregnancy (Gavrilova et al. 1997, Seeber et al. 2002). This effect of leptin binding may contribute to the greater body weight and associated increased body fat percentage of male relative to female rats (Reed et al. 1930). Indeed, age-related hyperleptinemia and increased food intake occur in male rats in association with reduced hypothalamic uptake of leptin (Fernandez-Galaz et al. 2001), and similar effects have been observed in diet-induced rodent models of obesity (Halaas et al. 1997, Van Heek et al. 1997, El-Haschimi et al. 2000). Interestingly, the present work confirms the clear sex difference (males> females) in hypothalamic $\mathrm{Ob}-\mathrm{Rb}$ protein expression previously reported for rats aged 51 days (Smith \& Waddell 2003a), but shows that this sex difference is lost by 7 months, coincident with a reduction in the sex difference in plasma leptin. Thus, the rise in plasma leptin in females between post-puberty and seven months of age may reflect a more leptin resistant state due to lower hypothalamic $\mathrm{Ob}-\mathrm{Rb}$.

While the placenta is clearly recognised as a major source of Ob-Re and thus plasma leptin binding activity in pregnant rodents (Gavrilova et al. 1997, Lammert et al. 2002, Smith \& Waddell 2002), the source of circulating $\mathrm{Ob}-\mathrm{Re}$ in non-pregnant rodents has remained uncertain.

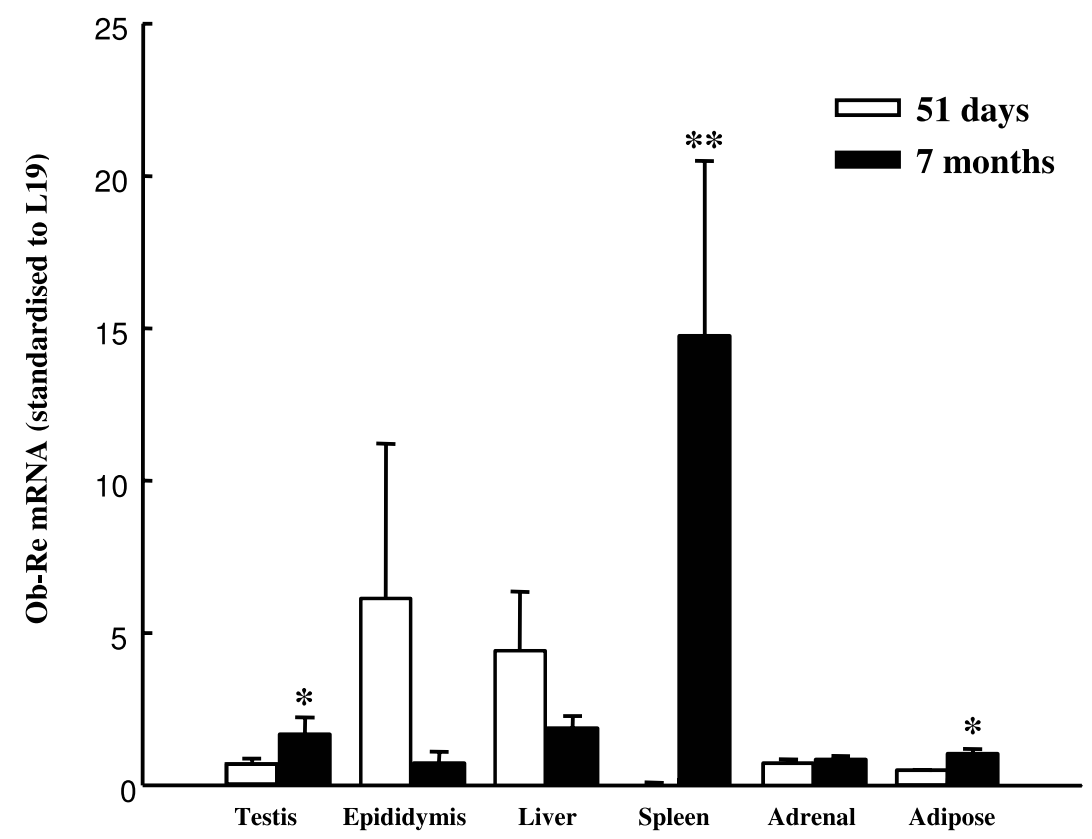

Figure 3 Expression of Ob-Re mRNA measured by real-time RT-PCR in various tissues from male rats immediately after puberty (p51) and at 7 months of age (adult $=7 \mathrm{mth}$ ). Values are expressed relative to L19 levels and are the mean \pm S.E.M of $n=3$ per group. There was significant variation among tissues $(P<0 \cdot 01)$ and with age $(P<0 \cdot 01)$ and significant interaction $(P<0.01)$. Therefore, age comparisons were made for each tissue by unpaired $t$-test. ${ }^{*} P<0 \cdot 05,{ }^{* *} P<0 \cdot 01$ compared with corresponding value at p51. 
Thus, one previous report provided no clear indication of Ob-Re mRNA expression by Northern analysis (Fei et al. 1997) whereas another detected Ob-Re mRNA by RT-PCR in a range of tissues but without accurate quantitation (Lollmann et al. 1997). We subsequently used quantitative RT-PCR to demonstrate $\mathrm{Ob}-\mathrm{Re}$ mRNA expression in the hypothalamus of both male and female rats, and to show a clear developmental increase in this expression in females (Smith \& Waddell 2003a). The present work extends these observations by showing that Ob-Re mRNA is expressed by several other tissues, most notably in the spleen where it increased more than 300 -fold from the immediate post-pubertal period to the adult. A role for leptin in the immune system is well recognised (Fantuzzi \& Faggioni 2000, Loffreda et al. 1998 ) and the spleen is known to express both Ob-Rb (Gainsford et al. 1996, Lollmann et al. 1997) and Ob-Re (Lollmann et al. 1997). Potentially, Ob-Re could play a local regulatory role within the spleen by mediating leptin access to $\mathrm{Ob}-\mathrm{Rb}$, and splenic secretion of $\mathrm{Ob}-\mathrm{Re}$ into the general circulation is likely to contribute significantly to plasma leptin binding activity. Among the other tissues examined, Ob-Re mRNA expression appeared relatively low, particularly in the adult, and as such these are likely to make only a relatively minor contribution to circulating Ob-Re.

In contrast to Ob-Re mRNA expression by several tissues in rodents, circulating leptin binding activity in humans is generated entirely by ectodomain shedding of membrane receptors (Maamra et al. 2001, Ge et al. 2002). It is possible that this shedding mechanism also operates in rodents, thus providing an additional source of circulating $\mathrm{Ob}-\mathrm{Re}$, but to our knowledge this possibility has not been investigated. In any event, regulation of leptin binding activity is likely to differ substantially between rodents and humans, and in this context it is noteworthy that the increase in plasma leptin binding activity from pre- to post-puberty in rats is opposite to the decrease in humans (Quinton et al. 1999, Kratzsch et al. 2002, Mann et al. 2003). The latter may facilitate puberty onset in humans by increasing leptin access to its hypothalamic targets, whereas in the rat, increased hypothalamic expression of Ob-Rb (Smith \& Waddell 2003a) would appear to be of greater importance to puberty onset.

\section{References}

Bennett PA, Lindell K, Wilson C, Carlsson LM, Carlsson B \& Robinson IC 1999 Cyclical variations in the abundance of leptin receptors, but not in circulating leptin, correlate with NPY expression during the oestrous cycle. Neuroendocrinology 69 417-423.

Burton PJ \& Waddell BJ 1994 11ß-Hydroxysteroid dehydrogenase in the rat placenta: developmental changes and the effects of altered glucocorticoid exposure. Journal of Endocrinology 143 505-513.

Burton PJ, Krozowski ZS \& Waddell BJ 1998 Immunolocalization of $11 \beta$-hydroxysteroid dehydrogenase types 1 and 2 in rat uterus: variation across the estrous cycle and regulation by estrogen and progesterone. Endocrinology 139 376-382.
Campfield LA, Smith FJ, Guisez Y, Devos R \& Burn P 1995 Recombinant mouse $\mathrm{OB}$ protein: evidence for a peripheral signal linking adiposity and central neural networks. Science 269 546-549.

Cheung CC, Thornton JE, Kuijper JL, Weigle DS, Clifton DK \& Steiner RA 1997 Leptin is a metabolic gate for the onset of puberty in the female rat. Endocrinology 138 855-858.

Clarke IJ \& Henry BA 1999 Leptin and reproduction. Reviews in Reproduction 4 48-55.

Duggal PS, Weitsman SR, Magoffin DA \& Norman RJ 2002 Expression of the long (OB-RB) and short (OB-RA) forms of the leptin receptor throughout the oestrous cycle in the mature rat ovary. Reproduction 123 899-905.

Edwards DE, Bohm RP Jr, Purcell J, Ratterree MS, Swan KF, Castracane VD, Henson MC 2004 Two isoforms of the leptin receptor are enhanced in pregnancy-specific tissues and soluble leptin receptor is enhanced in maternal serum with advancing gestation in the baboon. Biology of Reproduction 71 1746-1752.

Elefteriou F, Takeda S, Ebihara K, Magre J, Patano N, Kim CA, Ogawa Y, Liu X, Ware SM, Craigen WJ et al. 2004 Serum leptin level is a regulator of bone mass. PNAS 101 3258-3263.

El-Haschimi K, Pierroz DD, Hileman SM, Bjorbaek C \& Flier JS 2000 Two defects contribute to hypothalamic leptin resistance in mice with diet-induced obesity. Journal of Clinical Investigation 105 1827-1832.

Fantuzzi G \& Faggioni R 2000 Leptin in the regulation of immunity, inflammation, and hematopoiesis. Journal of Leukocyte Biology $\mathbf{6 8}$ 437-446.

Fei H, Okano HJ, Li C, Lee GH, Zhao C, Darnell R \& Friedman JM 1997 Anatomic localization of alternatively spliced leptin receptors $(\mathrm{Ob}-\mathrm{R})$ in mouse brain and other tissues. PNAS $\mathbf{9 4}$ 7001-7005.

Fernandez-Galaz C, Fernandez-Agullo T, Campoy F, Arribas C, Gallardo N, Andres A, Ros M \& Carrascosa JM 2001 Decreased leptin uptake in hypothalamic nuclei with ageing in Wistar rats. Journal of Endocrinology 171 23-32.

Gainsford T, Willson TA, Metcalf D, Handman E, McFarlane C, Ng A, Nicola NA, Alexander WS \& Hilton DJ 1996 Leptin can induce proliferation, differentiation, and functional activation of hemopoietic cells. PNAS 93 14564-14568.

Gavrilova O, Barr V, Marcus-Samuels B \& Reitman M 1997 Hyperleptinemia of pregnancy associated with the appearance of a circulating form of the leptin receptor. Journal of Biological Chemistry 272 30546-30551.

Ge H, Huang L, Pourbahrami T \& Li C 2002 Generation of soluble leptin receptor by ectodomain shedding of membrane-spanning receptors in vitro and in vivo. Journal of Biological Chemistry 277 $45898-45903$.

Halaas JL, Boozer C, Blair-West J, Fidahusein N, Denton DA \& Friedman JM 1997 Physiological response to long-term peripheral and central leptin infusion in lean and obese mice. PNAS 94 8878-8883.

Henson MC \& Castracane VD 2000 Leptin in pregnancy. Biology of Reproduction 63 1219-1228.

Huang L, Wang Z \& Li C 2001 Modulation of circulating leptin levels by its soluble receptor. Journal of Biological Chemistry 276 6343-6349.

Kastin AJ, Pan W, Maness LM, Koletsky RJ \& Ernsberger P 1999 Decreased transport of leptin across the blood-brain barrier in rats lacking the short form of the leptin receptor. Peptides $\mathbf{2 0}$ 1449-1453.

Kratzsch J, Lammert A, Bottner A, Seidel B, Mueller G, Thiery J, Hebebrand J \& Kiess W 2002 Circulating soluble leptin receptor and free leptin index during childhood, puberty, and adolescence. The Journal of Clinical Endocrinology and Metabolism 87 4587-4594.

Lammert A, Brockmann G, Renne U, Kiess W, Bottner A, Thiery J \& Kratzsch J 2002 Different isoforms of the soluble leptin receptor in non-pregnant and pregnant mice. Biochemical and Biophysical Research Communications 298 798-804. 
Lindell K, Bennett PA, Itoh Y, Robinson ICAF, Carlsson LMS \& Carlsson B 2001 Leptin receptor 5'untranslated regions in the rat: relative abundance, genomic organization and relation to putative response elements. Molecular and Cellular Endocrinology 172 $37-45$.

Loffreda S, Yang SQ, Lin HZ, Karp CL, Brengman ML, Wang DJ, Klein AS, Bulkley GB, Bao C, Noble PW et al. 1998 Leptin regulates proinflammatory immune responses. FASEB Journal 12 $57-65$.

Lollmann B, Gruninger S, Stricker-Krongrad A \& Chiesi M 1997 Detection and quantification of the leptin receptor splice variants $\mathrm{Ob}-\mathrm{Ra}, \mathrm{b}$, and, e in different mouse tissues. Biochemical and Biophysical Research Communications 238 648-652.

Maamra M, Bidlingmaier M, Postel-Vinay MC, Wu Z, Strasburger CJ \& Ross RJ 2001 Generation of human soluble leptin receptor by proteolytic cleavage of membrane-anchored receptors. Endocrinology 142 4389-4393.

Mann DR, Johnson AO, Gimpel T \& Castracane VD 2003 Changes in circulating leptin, leptin receptor, and gonadal hormones from infancy until advanced age in humans. The Journal of Clinical Endocrinology and Metabolism 88 3339-3345.

Nagatani S, Guthikonda P, Thompson RC, Tsukamura H, Maeda KI \& Foster DL 1998 Evidence for GnRH regulation by leptin: leptin administration prevents reduced pulsatile LH secretion during fasting. Neuroendocrinology 67 370-376.

Orly J, Rei Z, Greenberg NM \& Richards JS 1994 Tyrosine kinase inhibitor AG18 arrests follicle-stimulating hormone-induced granulosa cell differentiation: use of reverse transcriptase-polymerase chain reaction assay for multiple messenger ribonucleic acids. Endocrinology 134 2336-2346.

Pelleymounter MA, Cullen MJ, Baker MB, Hecht R, Winters D, Boone T \& Collins F 1995 Effects of the obese gene product on body weight regulation in ob/ob mice. Science $\mathbf{2 6 9}$ 540-543.

Quinton ND, Smith RF, Clayton PE, Gill MS, Shalet S, Justice SK, Simon SA, Walters S, Postel-Vinay M-C, Blakemore AIF et al. 1999 Leptin binding activity changes with age: The link between leptin and puberty. The Journal of Clinical Endocrinology and Metabolism 84 2336-2341.

Reed LL, Yamaguchi F, Anderson WE \& Mendel LB 1930 Factors influencing the distribution and character of adipose tissue in the rat. Journal of Biological Chemistry 87 147-174.
Seeber RM, Smith JT \& Waddell BJ 2002 Plasma leptin binding activity and hypothalamic leptin receptor expression during pregnancy and lactation in the rat. Biology of Reproduction $\mathbf{6 6}$ $1762-1767$.

Smith JT \& Waddell BJ 2000 Increased fetal glucocorticoid exposure delays puberty onset in postnatal life. Endocrinology 141 2422-2428.

Smith JT \& Waddell BJ 2002 Leptin receptor expression in the rat placenta: changes in ob-ra, ob-rb, and ob-re with gestational age and suppression by glucocorticoids. Biology of Reproduction $\mathbf{6 7}$ 1204-1210.

Smith JT \& Waddell BJ 2003a Developmental changes in plasma leptin and hypothalamic leptin receptor expression in the rat: peripubertal changes and the emergence of sex differences. Journal of Endocrinology 176 313-319.

Smith JT \& Waddell BJ $2003 b$ Leptin distribution and metabolism in the pregnant rat: transplacental leptin passage increases in late gestation but is reduced by excess glucocorticoids. Endocrinology 144 3024-3030.

Snedecor GW \& Cochran WG 1989 Statistical Methods, Ch 12, edn 8. Ames, Iowa: Iowa State University Press.

Takaya K, Ogawa Y, Isse N, Okazaki T, Satoh N, Masuzaki H, Mori K, Tamura N, Hosoda K \& Nakao K 1996 Molecular cloning of rat leptin receptor isoform complementary DNAs-identification of a missense mutation in Zucker fatty $(\mathrm{fa} / \mathrm{fa})$ rats. Biochemical and Biophysical Research Communications 225 75-83.

Tartaglia LA 1997 The leptin receptor. Journal of Biological Chemistry 272 6093-6096.

Van Heek M, Compton DS, France CF, Tedesco RP, Fawzi AB, Graziano MP, Sybertz EJ, Strader CD \& Davis HR Jr 1997 Diet-induced obese mice develop peripheral, but not central, resistance to leptin. Journal of Clinical Investigation 99 385-390.

Zakrzewska KE, Cusin I, Stricker-Krongrad A, Boss O, Ricquier D, Jeanrenaud B \& Rohner-Jeanrenaud F 1999 Induction of obesity and hyperleptinemia by central glucocorticoid infusion in the rat. Diabetes 48 365-370.

Zhang Y, Proenca R, Maffei M, Barone M, Leopold L \& Friedman JM 1994 Position cloning of the mouse obese gene and its human homologue. Nature 372 425-432.

Received 22 October 2004 Accepted 8 December 2004 